\title{
The Sustainability Dimensions: A Territorialized Approach to Sustainable Development
}

\author{
By Maria Coronato \\ University of Rome Tor Vergata
}

Abstract- The paper proposes the territory as the fourth dimension of sustainable development. Research starting from three dimensions of sustainable development - economic, social, environmental - highlights the difference between the spatial approach and the territorial approach in sustainable development practices. The paper shows that to include in the development approach the morphological (hilly, mountain, plain), functional (metropolitan or non-metropolitan city, cross border region), traditional (port city, financial city, industrial city), government (National strategy, special laws, etc.), governance (formal and not formal network, institutional/ noninstitutional body) aspects, leads to different development results than not including them. This evidence shows to distinguish development practices from sustainable development practices as emerged from recent Territorial Impact Assessment studies in which policies, through the territorialization of the results, guide planning actions: (local) planning actions selected on (general) policy objectives create the conditions for adaptation (about planning) and mitigation (about policies) of human actions on the environment, thus being able to speak of sustainable development.

Keywords: sustainable development, territorial approach, the territorial capital, territorial diversity, sustainability.

GJHSS-H Classification: FOR Code: 300903

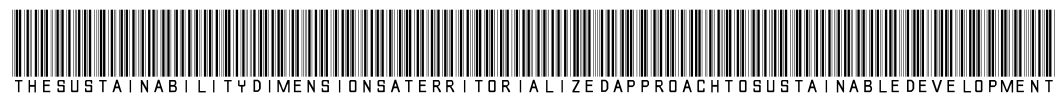

Strictly as per the compliance and regulations of:

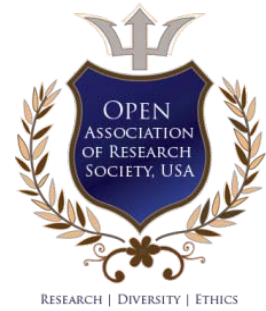

(C) 2020. Maria Coronato. This is a research/review paper, distributed under the terms of the Creative Commons AttributionNoncommercial 3.0 Unported License http://creativecommons.org/licenses/by-nc/ 3.0/), permitting all non-commercial use, distribution, and reproduction in any medium, provided the original work is properly cited. 


\title{
The Sustainability Dimensions: A Territorialized Approach to Sustainable Development
}

\author{
Maria Coronato
}

\begin{abstract}
The paper proposes the territory as the fourth dimension of sustainable development. Research starting from three dimensions of sustainable development - economic, social, environmental - highlights the difference between the spatial approach and the territorial approach in sustainable development practices. The paper shows that to include in the development approach the morphological (hilly, mountain, plain), functional (metropolitan or non-metropolitan city, cross border region), traditional (port city, financial city, industrial city), government (National strategy, special laws, etc.), governance (formal and not formal network, institutional/ noninstitutional body) aspects, leads to different development results than not including them. This evidence shows to distinguish development practices from sustainable development practices as emerged from recent Territorial Impact Assessment studies in which policies, through the territorialization of the results, guide planning actions: (local) planning actions selected on (general) policy objectives create the conditions for adaptation (about planning) and mitigation (about policies) of human actions on the environment, thus being able to speak of sustainable development.
\end{abstract}

Keywords: sustainable development, territorial approach, the territorial capital, territorial diversity, sustainability.

\section{INTRODUCTION}

- The Environment understood as a complex of natural and anthropogenic elements, is a complex and multilevel system where economic, social, and ecological dimensions, assessed at local scale, produce effects at global scale. Alterations of the local environmental system require global policy actions (i.e., Sustainable Development Goals - Agenda 2030) to be planned at a local scale based on of territorial specificities. However, sometimes the answers to the main local environmental problems appear 'out of reach' concerning to the political and programmatic intervention capacities of local communities. The transcalarity that characterizes environmental problems requires that environmental issues must be addressed looking a global scale, even if the impacts are measured mainly at the local level (Kennet, Gale de Oliveira, Heinemann, 2010).

The question between "adaptation" and "mitigation" policies concerning the multidimensionality of environment (from local to the global scale and vice versa). These expressions are mostly used about climate change policies but can also be used to a much broader scale that encompasses the whole set of

Author: University of Rome "Tor Vergata" Dept. Management and Law, Italy.e-mail: maria.coronato@uniroma2.it environmental policies. If it is, in fact, true that the mitigation of human impacts is the main goal to which the environment (ecological, social, and economic dimension) must strive by policy choices, it is by adaptation actions a local scale that this result can be achieved. Adaptation and mitigation are, therefore, not alternative or conflicting approaches. Rather they represent complementary aspects of a comprehensive and more successful policy that addresses the issues of the environmental system as a whole. If mitigation has a longer time to action and requires a globally coordinated approach to gradually reduce and ultimately control human impacts on the environment, it is the adaptation that acts primarily at the local level (from national to lower), and it can be modulated according to the territorial context taking into account the "territorial diversity". If the adaptation measures (assessed at local scale) are not well implemented, the mitigation costs and time-line (assessed at global scale) will be greater, and the consequences on the entire environmental system will be more serious.

Based on these considerations, the most recent positions on sustainable development have been formed. It is generally defined as development able to satisfy the needs of the current generation without compromising the satisfaction of future generations (WCED, 1987). This position requires global policies for planning and evaluation, capable of looking at the whole at the parts (social, ecological, and economic) of the system. Closely connected to this position are intragenerational equity which implies equal access to resources (both environmental, economic and social/ cultural) by all the citizens of the planet, without distinction concerning to the place where they live; and intergenerational equity, which implies equal opportunities for resources for current and future generations.

The link between environment and development is therefore based on endogenous resources (Spinelli et al., 1994), a "bottom-up" development that considers the territory as the starting point of a systemic analysis where the economy, society, ecology form a unicum that interacts with the rest.

Finding adequate and compatible solutions between environmental and development is the goal of sustainability. Strong and animated is the clash between the theorists of 'weak' sustainability (Solow, 1987), who believe that to guarantee the needs of future 
generations, it is necessary to leave a share of natural capital/artificial capital no less than the current one. It is therefore believed that the loss of natural capital can be compensated for by human made capital. The total replacement of fossil sources with renewable ones is hypothesized, but for this purpose the infrastructures will have to be adapted to allow energy already produced from renewable sources to compete with traditional ones (technocentrism). On the other hand, the 'strong' approach to sustainability (ecocentrism) excludes the substitutability of natural capital with that produced by man. Continuing an economy can be considered sustainable if the 'environment' loss is counterbalanced by an increase in the stock of material infrastructure (machinery or other artificial/physical capital). Some authors such as Ekins et al. (2003) think that strong sustainability is also justified based on some fundamental differences between the human made capital and the natural capital in relation to the reproducibility of the former and the irreversibility of the consumption of the latter. A possible balance between these two "forms" of sustainability is achieved by resorting to the concept of "critical" natural capital, that is, that part of natural capital that plays an irreplaceable role compared to other types of capital (Turner, 1993; de Groot, 2003). It is a question of identifying the critical level of natural capital to be preserved and the quantity of manmade capital that can act as a substitute for natural capital, called "sustainability limit".

A combination of man-made capital and natural capital together with the resources (material and immaterial), the production factors, skills, knowledge available on the territory constitute the so-called territorial capital (Camagni, 2009). The European Commission also has defined territorial capital as the complex of elements (tangible and intangible) available to the territory, which can constitute strengths or real constraints in relation to the aspects taken into consideration. Therefore, each region has a specific territorial capital able to generate a higher return for specific types of investment. Territorial development policies must first and foremost support and preserve the territorial capital localized (European Commission, 2005). Further evolutions on the subject lead to define territorial capital as a complex of elements (material and immaterial) available to the territory for its development: these elements can constitute strengths or real constraints depending on the aspects taken into consideration. Knowing the territorial capital of each territory helps to identify the types of investments with the highest return (Prezioso, 2019).

An approach to sustainability based on territorial capital asks to assume new parameters to calculate sustainable development, overcoming only the economic, social, and ecological aspects. If the term "capital" carries with it the idea of the necessary goods used to pursue pre-established objectives, the "territorial" attribute recalls the role of the territory as a factor for a bottom-up development, built on local potential and "territorial diversity", and that takes into account the multidimensionality of the relationships that are intertwined in the territory taking in charge geography, history, culture, population identity, skills and vocations present and regional territorial function (economic and political).

Assuming the concept of territorial capital based on the reasoning offers the advantage of being able to embrace different elements of the environment (in a broad sense) and to know and define (and therefore govern) adaptation and mitigation actions.

In a dynamic vision, there is a stock of territorial capital which must therefore be maintained, innovated, developed, and transmitted to future generations in the same logic adopted for sustainable development. In other words, territorial capital must be conceived not only as an endowment of a certain territory, which is only the starting point of the analysis, but also as an investment to build future choices according to a sustainable approach.

\section{DO SPATIAL OR TERRITORIAL APPROACH TOWARD SUSTAINABLE DEVELOPMENT? A TERRITORIAL EVIDENCE FROM THE USE OF TERRITORIAL IMPACT ASSESSMENT}

Territorial Impact Assessment is defined as an ex-ante mechanism that can be used to identify the potential impacts of political choices to assess better actions for specific territories about different territorial capital.

In 2007 the European Commission declare the Territorial Impact Assessment (TIA) as a tool to support policy/decision making without however ever replacing it. A tool therefore able to support an efficient legislation (national and regional) considering at one time the several interaction among sectoral policies in relation to the territorial capital.

To this end, the European Committee of the Regions (CoR) in 2015 included the TIA among the tools in use and useful for the action of the European Commission by inserting the territorial dimension in the Better Regulation package (EC, 2015) and the European Parliament (2015) calls for its systematic application to the urban dimension so that sectoral policies are correctly addressed to towns, cities, and larger functional urban areas, taking into account, as a matter of priority, three elements: balanced territorial development, territorial integration, and territorial governance, looking at the role of territorial areas on economic growth, job creation, sustainable development. 
The four TIA models currently to the attention of the European Commission (2020) ${ }^{1}$ have the purpose of declining the policy action about the territorial specificity so as to measure the ex-ante impact assessment of anthropic actions, estimating the interdependence relationships between socioeconomic, cultural, and environmental variables, adding them to traditional indicators of well-being (GDP, employment, productivity) (Faludi, 2016). Including the territorial specificity in the analysis is the crucial difference between a spatial approach and a territorial approach. The first considers a general solution to a political question; the second suggest solutions on the base of territorial diversity (Table 1).

Planning on the base of base of territorial specificity (also looking the functional relationships, Coronato 2019) can understand the development potential of each territory and which governance mechanism and planning actions is better on the base of the territorial typology (e.g., mountain areas, internal area, coastal areas, metropolitan city, protected area, islands, etc.) to increase the efficiency of investments (infrastructural, technological, production, etc.) (Prezioso, 2020).

A recent Italian research ${ }^{2}$ used the STeMA TIA model (Prezioso, 2020) to measure the territorial cohesion of the Italian regions and provinces, links the policy choices with development actions to implement at a local scale. The added value brought by the model was that it distinguishes the ex-ante time (before the policy choice) from the ex-post (following the policy choices) and from the ex-post territorialization analysis showing how the same policy action (selected ex-ante) produces different results (between ex-post and ex-post territorialized) on the basis of territorial diversity (morphological, functional components, etc.).

The STeMA methodology analyzed the Italian regions and provinces in light of the objectives of the Europe 2020 strategy: smart growth, sustainable growth, inclusive growth, adding a fourth component to assess the economic efficiency of investments. The methodology identified 7 Systemic Territorial Functional Typologies (STFT) (Prezioso, 2019a) which combine 5 types of settlement system, 4 large geomorphological units (mountain / hill / valley / plain) and related subunits:

1. MEGA and metropolitan systems with high urban influence and transnational/national functions that can facilitate cooperation between cities (or city parts) at regional, national and transnational levels.

\footnotetext{
${ }^{1}$ EATIA, STeMA, ESPON TIA Quick Check, TEQUILA

${ }^{2}$ Project Title "Territorial Impact Assessment of the Territorial Cohesion in the Italian regions. Place Evidence Model for Assessing Policies Devoted to Green Economy in Internal Area and Metropolitan Inner Peripheries" (PRIN 73 PI Maria PREZIOSO - 20155NXJ8T - SH3),
}

2. High urban influence systems with transnational/ national specialized functions that can facilitate urban-rural cooperation between authorities in interconnected areas at regional, national and transnational levels.

3. High urban influence systems without specialized functions and with few transnational/national functions that can facilitate urban-rural cooperation between authorities in interconnected areas at regional, national and transnational levels.

4. High urban influence systems without specialized functions and transnational/national functions, thus not able to facilitate urban-rural cooperation between authorities in interconnected areas at regional, national and transnational levels.

5. Low urban influence systems with regional/local specialized functions that can facilitate urban-rural cooperation between authorities in interconnected areas at regional, national and transnational levels.

6. Low urban influence systems with regional/local functions that can facilitate urban-rural cooperation between interconnected areas at regional and local levels.

7. Low urban influence systems without specialized functions and transnational/national functions, thus not able to facilitate urban-rural cooperation between authorities in interconnected areas at regional, national and transnational levels.

The evidence of the research, of which the case of the Umbria Region is reported below (Coronato, 2020), shows that the territorial dimension, together with ecological, economic and social aspects, adds information on the measure of the efficiency of policy choices to achieve the sustainable development. 
Table 1: Spatial and Territorial Approach: an example

\begin{tabular}{|c|c|c|c|c|c|}
\hline $\begin{array}{c}\text { Policy } \\
\text { question }\end{array}$ & $\begin{array}{c}\text { Spatial } \\
\text { Approach }\end{array}$ & \multicolumn{4}{|c|}{ Territorial Approach } \\
\hline & $\begin{array}{c}\text { Policy } \\
\text { choices }\end{array}$ & $\begin{array}{l}\text { Territorial } \\
\text { Analysis }\end{array}$ & Answer & Analysis & $\begin{array}{c}\text { Policy } \\
\text { choices }\end{array}$ \\
\hline \multirow{4}{*}{$\begin{array}{l}\text { Low Third } \\
\text { educational } \\
\text { level }\end{array}$} & $\begin{array}{l}\text { Increase the } \\
\text { educational } \\
\text { supply }\end{array}$ & $\begin{array}{l}\text { Which is the } \\
\text { territorial system } \\
\text { where implement } \\
\text { the policies to } \\
\text { increase the } \\
\text { education score? }\end{array}$ & $\begin{array}{l}\text { It is an internal } \\
\text { area where } \\
\text { insist only } \\
\text { primary and } \\
\text { secondary } \\
\text { educational } \\
\text { supply }\end{array}$ & \multirow{4}{*}{$\begin{array}{l}\text { The territory } \\
\text { don't supply an } \\
\text { high level } \\
\text { education. The } \\
\text { areas in } \\
\text { "internal" so it is } \\
\text { not connect with } \\
\text { the main city. } \\
\text { The average } \\
\text { age is high and } \\
\text { the economic } \\
\text { specialization is } \\
\text { the } \\
\text { manufacturing }\end{array}$} & $\begin{array}{l}\text { Support the } \\
\text { e-learning }\end{array}$ \\
\hline & $\begin{array}{l}\text { Economic } \\
\text { support } \\
\text { the family }\end{array}$ & $\begin{array}{l}\text { What is the } \\
\text { average age of } \\
\text { the resident? }\end{array}$ & 60 years old & & $\begin{array}{l}\text { Increase the } \\
\text { physical } \\
\text { accessibility } \\
\text { of the area }\end{array}$ \\
\hline & . & $\begin{array}{l}\text { What is the main } \\
\text { economic } \\
\text { specialization of } \\
\text { the area? }\end{array}$ & Artisanship & & $\begin{array}{l}\text { Increase the } \\
\text { supply to Life } \\
\text { Long } \\
\text { Learning }\end{array}$ \\
\hline & & & & & \\
\hline
\end{tabular}

\section{ili. Do Spatial or Territorial Approach Toward Sustainable Development? A TERritorial EVIDENCE FROM THE USE OF Territorial Impact Assessment}

Umbria is a region of central Italy, located in the heart of the peninsula, called "the green heart of Italy". It has an area of $8,456 \mathrm{~km}^{2}$ (of which 6,334 in the province of Perugia and 2,122 in the province of Terni) and a population of 878540 inhabitants. It is the only Italian region not bathed by the sea and borders on Abruzzo, Lazio, Marche and Tuscany regions.

Umbria has been included in the "Snodo 2 territories" (MIT, 2014) aimed at realizing a partnership system among Abruzzo, Lazio, and Marche regions (socalled Macroregion of the 'Italia di Mezzo') for the establishment of a cooperative macro-region. In this framework, in implementation of the program dedicated to "Snodo 2 territories", the Macroregion of the "Italia di Mezzo' has to support both the networking and enhancement of naturalistic and environmental resources for tourism purposes and the development of sustainable widespread cities. The Umbria Region is, in fact, characterized by a "widespread" settlement model with a greater concentration in urban and peri-urban areas with consequences that impact the organization, and management of services (transport, health, education, etc.), in particular the network ones. However, the urban sprawl of the Umbria Region is a potential development opportunity for the regional "internal areas" by adapting the quality and quantity of essential services (school, health and transport) to generate that turnaround (including job demand) that in recent decades has led to a demographic escape from these areas (so-called: marginal) to better-served territories. In this regard, Umbria Regional Law $\mathrm{n}$. 10/2015 sets the criteria for rationalizing services in line with the associated forms of the municipalities (Union of Municipalities by the Delrio Law) around which area characterized by different levels of the spatial periphery gravitate (DPS 2014).

The Umbria Region is therefore inserted in the urban and infrastructural context of central Italy, according to a reticular model that integrates the different networks (transport, people, things, information, the network of energy infrastructures, hygiene, and health), exceeding the vision of the "City Region" by focusing on the cooperation mechanisms, especially of the transregional areas. The territorial and political approach turning towards a new territorial model of multilevel polycentrism in which the two anime - "Umbria, a joint territory" (geographic and infrastructural point of view) and "Umbria, the green region of Italy"- work cohesively and integrated as planned into Territorial Strategic Plan - DST (2008). This approach also takes into account the main morphological and environmental aspects of the regional territory (Tevere Valley, Apennines) and the settlement and production structure of the territory. In this regard, the transport infrastructures are to be implemented in relation to the role of Umbria in the national context (Figure 1). 


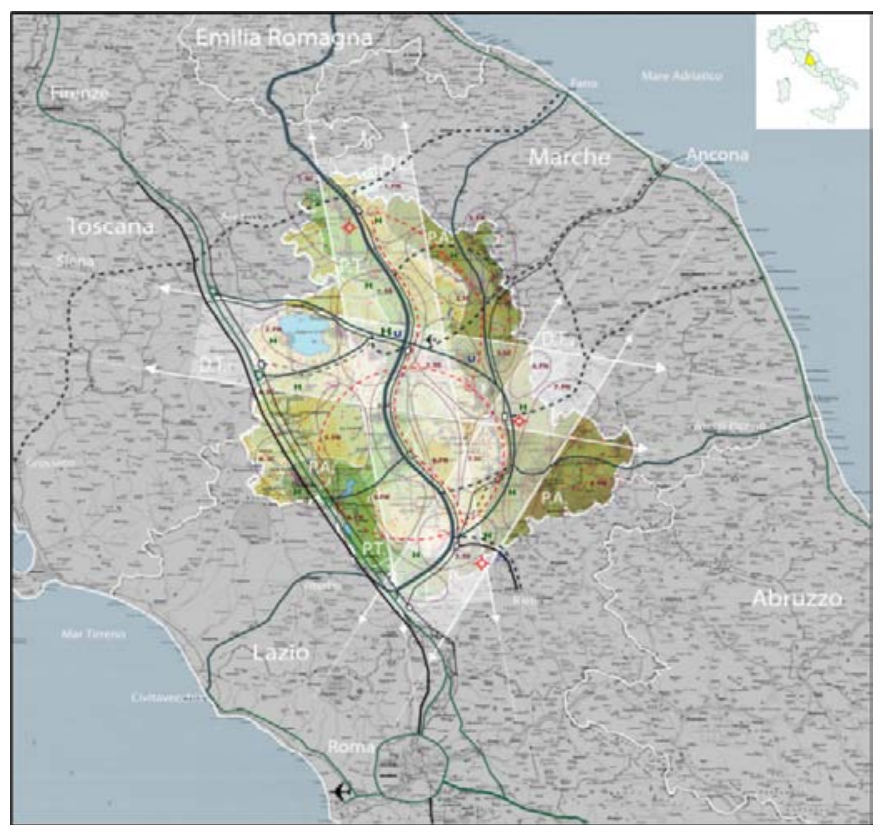

\begin{tabular}{|c|c|}
\hline \multicolumn{2}{|c|}{ Legend } \\
\hline Longitudinal direction North - South & $\mathrm{DL}$ \\
\hline System of the East-West transversal lines & $\mathrm{DT}_{1} ; \mathrm{DT}_{2}$ \\
\hline Tevere Project & $\mathrm{PT}$ \\
\hline Appennine Project & $\mathrm{PA}$ \\
\hline Center of roadband connection & :-: \\
\hline
\end{tabular}

(Source: Territorial Strategic Plan (DST, 2008), Plan's Cartography)

Figure 1: Territorial Strategic Plan

In the national context, the Umbria Region presents itself as a hub and as such has the role of communicating the vital areas of the country-system preserving own identity (DST, 2008, p. 1). For this purpose, the infrastructure project "Snodo 2 territory" connects the Tyrrhenian (Civitavecchia hub), Adriatic (Ancona hub) to the Orte-Ravenna central route, directly connecting to Corridor 1 Berlin-Palermo on which other systems such as the Quadrilatero Umbria - Marche for the strengthening of the transversal infrastructure connections between the two regions. Umbria Region is also affected by an interregional territorial platform, called the "Central Apennines", which concerns the Terni area and its connections with Rieti province and Abruzzo Region, which the Ministry of Infrastructures includes among those of a strategic nature and which it develops along the road links of the Terni-Rieti and the Terni-L'Aquila railway line, bringing together urban systems and territories rich in environmental and cultural values (DST, 2015, p. 4).

However, Umbria is affected not only by physical but also ecological infrastructure projects (e.g. "The Tiber and its tributaries" project) and by the network of rural villages or thematic trails, as well as by the reorganization of Umbrian cities into networks built around specific themes or projects. With reference to the role of Umbria in the national context, the traditional image of Green Umbria or "Umbria, the green heart of Italy" has been replaced with "Umbria sustainability laboratory" which places at the center of territorial and development policies the environmental quality and landscape.

The existing projects have a supra-municipal dimension, often macro-regional, which aims to increase attractiveness (in terms of services and job opportunities) by investing in border areas to combat external migration to Tuscany, Latium and Marche according to a multilevel reticular polycentrism oriented not only to physical and/or ecological infrastructures but also to improve the organizational and service delivery levels - also using soft governance mechanisms (Coronato and Al, 2019) - to reach European targets by increasing the level of territorial cohesion within the region whose main strategic objectives are (DPS, 2015 p. 13 and 14):

- Counter the risk of regional isolation;

- Encourage forms of coordination between the centers (community of municipalities, consortia, thematic networks);

- Encourage the qualification and environmental, landscape and social sustainability of interventions 
in city networks, with particular regard to the enhancement of cultural heritage, residence, services of collective interest, public spaces;

- Improve cross-connections between centers, strengthening the network system between urban nodes of different rank, with particular regard to local settlement systems in marginal areas;

- Implement integrated territorial projects (mobility, soil protection-energy distribution);

- Encourage the establishment of business networks and production consortia;

- Strengthen communication and information networks technologically (broadband network).

Based on these regional strategic objectives, starting from the status quo (ex-ante), the STeMA methodology was questioned by selecting possible development actions. From the comparison between exante and ex-post it was possible to evaluate whether the selected action triggered a development process or not. Finally, the analysis was carried out with territorialization, that is, it was assessed whether the development triggered by the selected policy action would bring a real advantage for the territory ${ }^{3}$ under study.

The table below (Table 2) summarizes the results of the query divided by the 4 STeMA determinants. For each determinant, the ex-ante and expost results were reported in the two approaches, spatial and territorial. While the spatial approach measures the distribution by class of indicators such as quantities used by the model; the territorial approach weighs (evaluates) the same indicators as before according to the territorial typology of the study area (for example: city with metropolitan function, capital city, province, rural area, hilly area, etc.). To clarify this aspect ${ }^{4}$, it is enough, among other things, to think of the distribution of digital services: having a scarce supply of digital services in a metropolitan city like Rome, government headquarters, where service companies reside, with a high educational and healthcare offer, etc. it requires a more urgent intervention than the same result but obtained in a poorly urbanized rural town. With the same result, the spatial approach indicates that there is a need to invest in infrastructures to provide digital services; the territorial approach gives us the size of the problem according to the territorial typology of the area affected by the problem and consequently provides elements of support to the political decision maker in relation to the resources to be invested.

The choices made have led to an improvement in both approaches compared to ex ante but it is the positive increase in territorialization that confirms the goodness of the choices in relation to the area of study and how incisive the intervention must be depending on the territorial typology in which it will have to take place.

Table 2: Spatial and territorial approach used in Umbria Region by STeMA ${ }^{5}$

\begin{tabular}{|c|c|c|c|c|}
\hline \multirow[t]{2}{*}{ STeMA Determinants } & \multicolumn{2}{|c|}{$\begin{array}{c}\text { Spatial approach used in Umbria } \\
\text { Region }\end{array}$} & \multicolumn{2}{|c|}{$\begin{array}{c}\text { Territorial Approach used in Umbria } \\
\text { Region }\end{array}$} \\
\hline & En ante & Ex post & Ex ante & Ex post \\
\hline SMART GROWTH & $C \rightarrow$ & B & $E \rightarrow$ & D \\
\hline SUSTAINABLE GROWTH & $\mathrm{B} \rightarrow$ & $A$ & $D \rightarrow$ & C \\
\hline INCLUSIVE GROWTH & $C \rightarrow$ & B & $E \rightarrow$ & D \\
\hline RESOURCH AND FUNDS & $\mathrm{D} \rightarrow$ & C & $\mathrm{F} \rightarrow$ & E \\
\hline
\end{tabular}

Spatial approach class break $A=$ very high; $B=$ high; $C=$ low; $D$ : Very low;

Territorial Approach class break $A=$ Absolute; $B=$ Very high; $C=$ High; $D=$ Medium; $E=$ Low; $F=$ very low

\section{A New Dimension of Sustainability: Territorial Sustainability}

In relation to these aspects, the content and objectives of territorial planning have significantly changed. A planning understood as a policy of controlling and guiding the organization of space as a physical entity - land use, organization of transport

\footnotetext{
${ }^{3}$ STeMA methodology classified the Province of Perugia as Low Urban influence Systems in 4 different morphological typologies, with transnational / national specialized functions able to make rural cooperation between interconnected areas at regional, national, transnational level Transnational or National functions" and the Province of Terni as Low Urban influence Systems territories in 4 different morphological typologies, with regional / local functions, not able to make rural cooperation between interconnected areas at regional, local level Regional / Local fucntions
}

systems, public services - has gradually been replaced by a concept of planning as a tool for achieving better distribution of resources among the groups settled on the territory: this implies the consideration of the effects that a decision (or a set of decisions) can produce on the conditions of well-being of the population living in a specific spatial reality (Prezioso, 1995 and 2003; Conti, 2012).

\footnotetext{
${ }^{4}$ The whole analysis is in Prezioso 2019 and 2020

5 The different number of class break (four in the spatial approach; six in the territorial approach) depends on the fact that the territorial approach takes into account the territorial systems listed by the STeMA methodology (Prezioso, 2019b)
} 
This new approach to the environment and planning (territorial in the strict sense in a more broad context of "resources") has innovated the dimensions that measure sustainable development.

The need to reconcile economic growth and equitable distribution of resources arises from the awareness that economic growth alone would soon cause the collapse of natural systems. Hence the need to combine the three dimensions of development:

- Environmental sustainability is understood as the ability to preserve the three functions of the environment over time: resource supplier, waste receiver, and direct source of utility. Within a territorial system, environmental sustainability means the ability enhancing the environment as a "distinctive element" of the territory, while ensuring the protection and renewal of natural resources and heritage.

- Economic sustainability - can be defined as the ability of an economic system to generate lasting growth of economic indicators. In particular, the ability to generate income and work for the livelihood of populations. Within a territorial system, economic sustainability means the ability to produce and maintain the maximum added value within the territory by effectively combining resources, to enhance the specificity of local products and services;

- Social sustainability can be defined as the ability to guarantee conditions of human well-being (safety, health, education) equally distributed by class and by gender. Within a territorial system, social sustainability means the ability of the subjects to intervene together, effectively, on the basis of the same concept of the project, encouraged by consultation between the various institutional levels.

Sustainable development is generally defined as the point of equilibrium (of intersection) between the economic, social and environmental systems, underlining with this only two of its dimensions are privileged, sustainable development does not occur (but development from a perspective conservationist, ecologist or merely socio-economic). Table 3 shows some examples of intersectionality $(\cap)$ among the policies attributable to the various dimensions of sustainability.

Table 3: The intersectionality of policies: an example

\begin{tabular}{|c|c|c|c|c|}
\hline \multicolumn{5}{|c|}{ Development } \\
\hline Environmental Sustainability & $\cap$ & Economic Sustainability & $\cap$ & Social Sustainability \\
\hline $\begin{array}{l}\text { Reduction of environmental loads } \\
\text { Protection of biodiversity }\end{array}$ & $\cap$ & $\begin{array}{l}\text { Sustainable use of resources } \\
\text { Growth }\end{array}$ & $\cap$ & Health \\
\hline Clean energy & $\cap$ & $\begin{array}{l}\text { Employment } \\
\text { Fight against poverty } \\
\text { Supply of territorial services }\end{array}$ & $\cap$ & $\begin{array}{l}\text { Education } \\
\text { Inclusion } \\
\text { Accessibility }\end{array}$ \\
\hline Sustainable use of resources & $\cap$ & Mitigation and adaptation & $\cap$ & Access to the resource \\
\hline & $\cap$ & 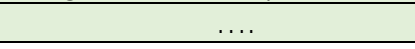 & $\cap$ & \\
\hline
\end{tabular}

The actions resulting from the intersectoral policies do not provide us with the size of the intervention because they miss any information related to the territorial capital. For this reason, seems appears appropriate to add the territorial dimension to the others, so to analyze in terms of policy actions - on the one hand -, and territorial capital on the other, the complex of economic, ecological and social relations that site. This scope is necessary to apply a systemic, transscalar, flexible and dynamic vision that, through policies, moves between the various levels of programming, from local to global, from adaptation (local) to mitigation (global). Policies relating to climate change, energy, services of general interest, territorial and maritime planning, environmental protection although they have elements attributable to each of the classic dimensions of sustainability (impact in terms of emissions, employment, growth, industry, wealth, etc.) for their transversal policy action converge in territorial sustainability and suggest the use of forms of macroregional, sometimes trans-regional or cross-border cooperation and increasingly flexible governance mechanisms ("soft governance"). Only with the addition of the territorial dimension can we truly evolve towards a new approach to development - a sustainable development - to be planned to increase the internal resilience of the systems by investing in local territorial capital.

The four dimensions are closely interrelated by a multiplicity of connections and, therefore they must not be considered as independent elements, but must be analyzed in a systemic vision, as elements that together contribute to the achievement of a common goal: sustainable development. This means that every programming intervention must take into account the reciprocal interrelationships. If planning choices favored only some of the dimensions, sustainable development would not occur. The intersectoral nature of environmental policies therefore makes it necessary to work simultaneously on all dimensions of sustainability until a balance is found between the parties. If it is true that the "sustainability limit" is given by a balance between the dimensions of sustainability where the economic, ecological, and social dimensions pertain to 
policy objectives (growth, employment, reduction of environmental loads, clean energy, safety, education, etc.), it is the territorial dimension that through systemic territorial relations (metropolitan city, metropolitan area, internal area, marginal area, etc.), programming, capacity building, local resources can find efficient and sustainable solutions. Including the territorial dimension in the local planning process is useful to achieve the global policy objectives.

To represent the dimensions of sustainability on a Cartesian level by placing Planning - Local Adaptation on the x-axis, and the Policy Process - Global Mitigation on the $y$-axis, the more the local planning is consistent with global objectives, the more the mitigation effect increases globally (policy goal). In a spatial vision, development is obtained from a balance between economic, social and environmental sustainability. Still, as the evidence shows (CFN. Tab 2), the same actions produce different effects depending on the reference territory. To become sustainable, development must, therefore integrate the territorial component (Figure 2).

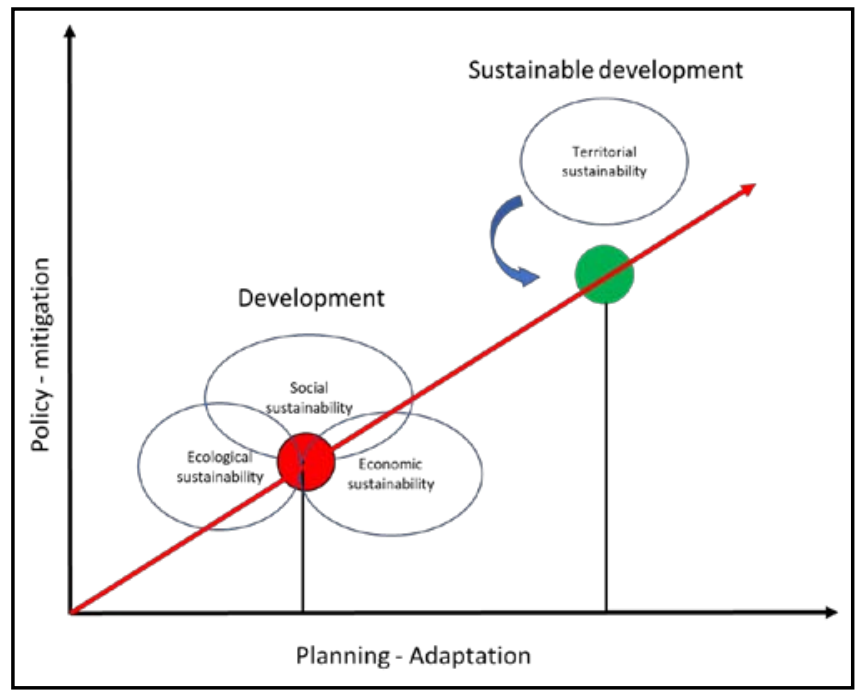

(Source: Author's elaboration)

Figure 2: The territorial approach toward the sustainable development.

\section{Conclusion}

The environmental and economic crisis and social poverty is central in the international policy objectives. It requires finding systemic and intersectoral solutions able to protect the scarce resources available by providing local-scale (adaptation) actions capable of generating a development process of a long term, which even on a global scale, generates positive (mitigation) impacts. This awareness strongly pushes us to think according to a territorial approach to planning the quantitative measure of a phenomenon needs to be territorialized, taking into account functional territorial systems. This highlights the difference between a spatial approach and a territorial approach to planning/policy. Finding a balance between the parts of the system and at the same time, considering the territory as a distinctive element of the analysis is also the basis of the transition from development to sustainable development, which in line with the declarations, is intergenerational and intragenerational. The nonterritorialization of planning/policy choices generates uncertainty about the consumption/use of natural, economic and social resources, producing a loss of territorial capital that is difficult to reproduce. The mitigating impacts are nothing more than the sum of individual local adaptation actions. Acting locally by implementing suitable and specific adaptation actions for each territory (territorial approach) to achieve the global policy (impact mitigation) makes it possible to talk about sustainable development.

\section{References Références Referencias}

1. Camagni, R. (2009). Per un concetto di capitale territoriale. in Borri, D., Ferlaino, F. (Ed), Crescita e sviluppo regionale: strumenti, sistemi, azioni, Scienze Regionali, n. 41, pp. 66-91.

2. Conti, S. (2012). I Territori dell'economia. Fondamenti di geografia economica. Novara, UTET

3. Coronato, M. (2020). Territorial cohesion assessment of Umbria Region. in Prezioso, M. (a cura di), Territorial Impact Assessment of the Territorial Cohesion in the Italian Regions. Model, on a place evidence bases, for the evaluation of policies aimed at the development of the green economy in internal areas and metropolitan peripheries.

4. Coronato, M. \& Prezioso, M. (2019). The Network of Protected Areas (NPA) as an Instrument to Implement Cross-Border Public Services. in Urban 
Sci., 3, 97. 2019 https://doi.org/10.3390/urbansci 3030097 (registering DOI) - 03 Sep 2019.

5. De Groot, D. (2003). Identifying critical natural capital: Conclusions about critical natural capital. Ecological economics 44 (2), pp. 277-292

6. Dipartimento per lo Sviluppo e la Coesione Economica - DPS (2014). Strategia nazionale per le Aree interne: definizione, obiettivi, strumenti e governance. Available at https://www.miur.gov.it/ documents/20182/890263/strategia nazionale_aree interne.pdf/d10fc111-65c0-4acd-b253-63efaé626b 19 (5th January 2020).

7. Disegno strategico territoriale - DST - Regione Umbria (2008). Available at http://www.umbriageo. regione.umbria.it/pagine/documentazione-delpiano-001 (5th January 2020)

8. EC - European Commission (2005). Impact Assessment Guidelines, SEC 791, EC, Bruxelles

9. EC - European Commission (2009). Impact Assessment Guidelines, SEC(2009) 92, Bruxelles

10. Ekins, P., Simon, S., Deutsch, L., Folke, C. \& De Groot R. (2003). A framework for the practical application of the concepts of critical natural capital and strong sustainability. in Ecological Economics, 44, pp. 165-185.

11. Kennet, Gail de Ilveira \& Heinemann (2010). The Green Economy, in Book of the year: Encyclopedia.

12. Ministero delle Infrastrutture e dei Trasporti (2014). Programma territorio snodo 2, Roma, MIT.

13. Prezioso M. (1995). La base geoeconomica della VIA. Pacini, Pisa.

14. Prezioso M. (2003). Pianificare in sostenibilità. Natura e finalità di una nuova politica per il governo del territorio. Roma, Adnkronos Libri.

15. Prezioso M. (2019a). Measuring the Progress towards Territorial Cohesion: a TIA Application to the Regional Development Programs. In ESPON 2020 Scientific Conference, Building the Next Generation of Research on Territorial Development. Scientific Report, 62-68.

16. Prezioso, M. (2019b). Methodological Approach for a New Economic Geography of the Territorial Cohesion in Europe and Italy, Bollettino della Società Geografica Italiana serie 14, 2 Special Issue: 21-24. Doi: 10.13128/bsgi.v2i3.708

17. Prezioso, M. (2020) (Ed). Territorial Impact Assessment of national and regional territorial cohesion in Italy. Place evidence and policy orientations towards European Green Deal. Bologna Patron. ISBN 9788855534860.

18. Solow, R.M. (1987). Growth Theory and After. Nobel Prize in Economics documents 1987-1, Nobel Prize Committee.

19. Spinelli, G. \& Scarpelli, L. (1994). Ambiente, economia, ecosistemi. Dai limiti dello sviluppo alla sostenibilità. Appunti dalle lezioni di geografia economica (Appunti dalle lezioni di Geografia economica), Roma, Edizioni Kappa.

20. Turner, R.K., Pearce, D.W. \& Bateman, I. (1993). Environmental Economics: An elementary Introduction.

21. Hemel Hempstead: Harvester Wheatsheaf.

22. WCED- World Commission on Environment and Development (1987). Our Common Future, Available at http://www.un-documents.net/our-commonfuture.pdf 